\title{
12. BIOTURBATION AND TRACE FOSSILS IN DEEP SEA SEDIMENTS OF THE WALVIS RIDGE, SOUTHEASTERN ATLANTIC, LEG 741
}

\author{
Dieter K. Fütterer, Geologisch-Paläontologisches Institut der Universität Kiel, D-2300 Kiel, \\ Federal Republic of Germany
}

\begin{abstract}
Trace fossil distribution present in pelagic carbonates cored on the Walvis Ridge during Deep Sea Drilling Project Leg 74 are described. A characteristic deep-sea trace fossil assemblage comprising the cosmopolitan ichnogenera Planolites, Chondrites, Zoophycos, and Teichichnus was found at paleo-water-depths ranging from a few hundred to about $4500 \mathrm{~m}$. Paleodepth distribution indicates that Zoophycos has changed its environmental preference from relatively shallow water in the Cretaceous into deeper water in the late Paleocene. Thus Zoophycos can be used as a paleodepth indicator in the bathyal environment if its stratigraphic age is known.
\end{abstract}

\section{INTRODUCTION}

Bioturbation is the churning, stirring, and reworking of a sediment by bottom-dwelling benthic organisms. In most cases it obliterates primary sedimentary structures and thus any information on the environmental conditions during sedimentation. Increasing bioturbation eventually results in a nearly complete homogenization of the sediment.

However, distinctly shaped sedimentary features produced by the activity of bottom-dwelling organisms (known as trace fossils, ichnofossils, or lebensspuren) record and report a part of the life activities of the benthic fauna and give evidence of the paleoecological conditions of the depositional environment. Thus vertical profiles of long, continuous sediment cores should exhibit biogenic structures revealing the history of activity of bottom-dwelling animals at a given site and the relation of that activity to changing environmental conditions.

Environmental significance of bottom-dweller activity or of trace fossil communities initially was considered to be essentially bathymetrically controlled (Seilacher, 1967). This emphasis on depth as the sole controlling environmental factor has been replaced by consideration of several more important parameters (e.g., water turbulence and currents, composition and stability of the substrate, aeration of water and sediment, sedimentation rates and food supply, diagenetic processes, evolutionary processes, etc.), all of which are more or less indirectly depth-related. These are now viewed as controls on the deep-sea benthic community (Seilacher, 1978). During Leg 74 of the Deep Sea Drilling Project a suite of five sites was drilled on the Walvis Ridge (Fig. 1). These sites extend from the Ridge crest down its northwestern flank into the Angola Basin in modern water depths ranging from $1054 \mathrm{~m}$ (Site 526) to $4428 \mathrm{~m}$ (Site 527). All sites are located on oceanic crust of late

\footnotetext{
${ }^{1}$ Moore, T. C., Jr., Rabinowitz, P. D., et al., Init. Repts. DSDP, 74: Washington (U.S. Govt. Printing Office).
}

Cretaceous age. Normal subsidence of the Walvis Ridge produced paleodepth core profiles passing from relatively shallow initial paleo-water-depths continuously to their present-day positions, which are in some cases $2000 \mathrm{~m}$ deeper.

Continuous coring by the hydraulic piston corer (HPC) produced very good recovery and only minor drilling disturbance in the unconsolidated sediments. These prerequisites offered an ideal opportunity to collect continuous data on the distribution of trace fossils through time and to relate those data to systematic changes in water depths in the open ocean.

\section{MATERIAL}

The observations presented here are based mainly on extensive shipboard macroscopic examinations of the complete sediment sequences and were supplemented by subsequent shore-based investigations of photographs of vertical core sections. The photographs were used to obtain semiquantitative data on the overall intensity of bioturbation and distribution of specific trace fossils. These observations are more detailed and closely spaced than the site chapters indicate. Additional samples may be included in more detailed shore-based investigations, using larger and/or horizontal core slabs and microscopical studies of thin sections of the more indurated material. X-radiographs from soft sediment sequences, however, are completely missing for technical reasons. Lithologically the sediments recovered during Leg 74 are nearly uniform at all sites. The dominant lithologies from top to bottom are generally nannofossil or foraminifer-nannofossil ooze grading into ooze and chalk sequences, with a decreasing ratio of ooze to chalk and increasing volcaniclastic sediments in the Paleocene to Upper Cretaceous chalk sequence. The carbonate content is higher than $90 \%$ throughout most of the sequences but tends to decrease as the detrital volcanic component increases.

\section{TRACE FOSSILS}

As in many previous studies on deep-sea trace fossils from DSDP cores, diversity is low (Warme et al., 1973; 


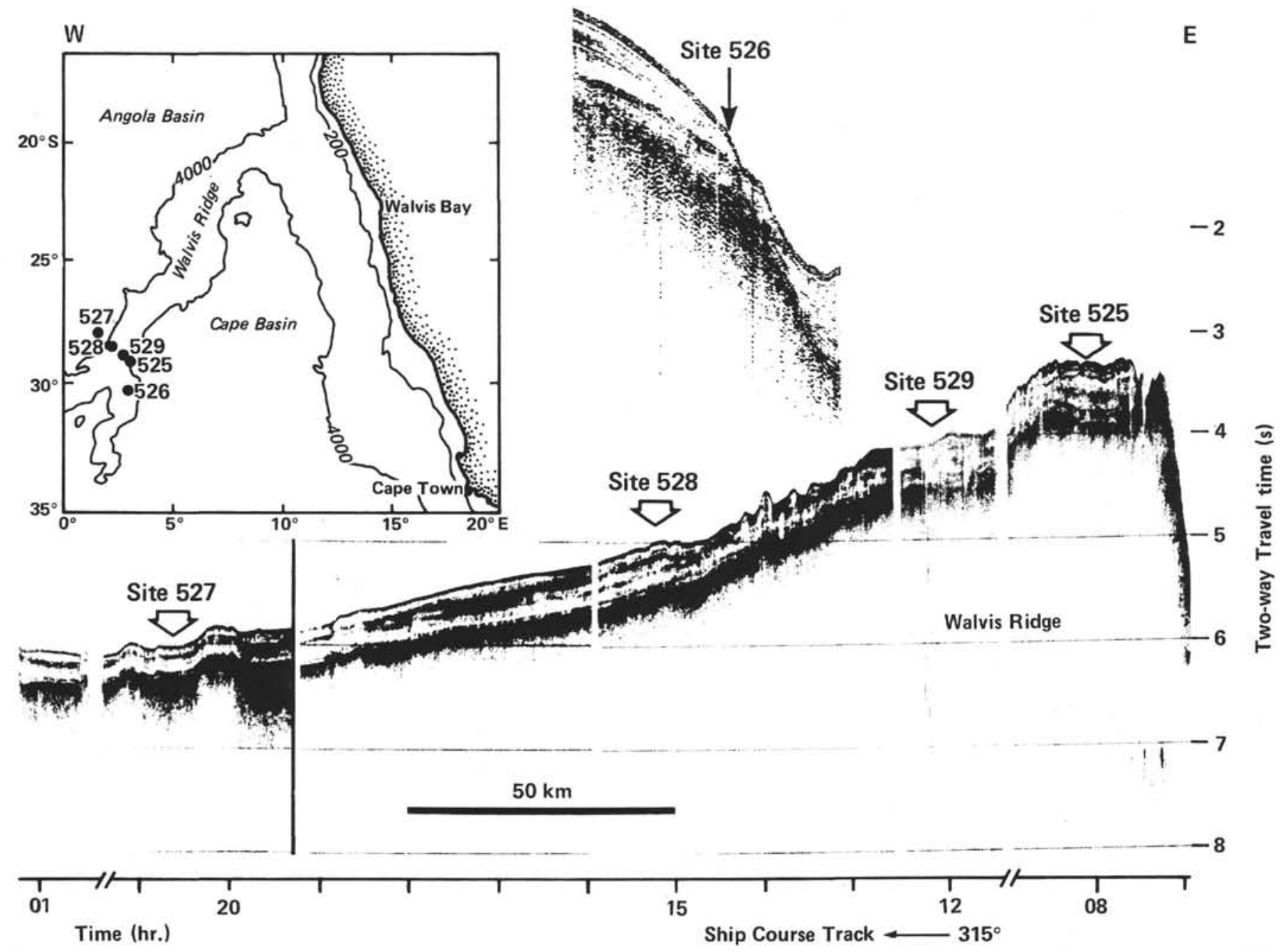

Figure 1. Index map showing geographic position and bathymetry of the Walvis Ridge and locations of Leg 74 Sites 525-529.

van der Lingen, 1973; Nilsen and Kerr, 1979; Ekdale, 1974, 1978, 1980; Chamberlain, 1975). Most traces belong to the ichnogenera Planolites, Zoophycos, and Chondrites and a smaller number to Teichichnus. Several types of halo burrows, pyritized burrows, and composite burrows are common, whereas larger vertical burrows occur only locally.

Planolites is the most common trace fossil in Leg 74 cores (Plate 1, Figs. 1, 2). It is a simple, sometimes inclined, dominantly horizontal burrow. It is generally straight, sometimes meandering slightly across the bedding planes and with few characteristic features. In cross section it is circular or oval, tending to appear lense-shaped in oblique section and normally ranging from a few to more than $10 \mathrm{~mm}$ in diameter. It is sometimes darker, sometimes lighter, than the surrounding sediment. Very oblique sections can give a pseudobedding appearance. Many of the Planolites burrows are not simple solitary burrows but interspersed with Chondrites. In most cases, however, undefinable lighter or darker structures occur, indicating a continuous transition to the composite burrow type (Plate 1, Fig. 3). For purposes of this chapter such burrows are lumped with Planolites.
Zoophycos burrows are presumably the most conspicuous and hence one of the easiest trace fossils to recognize in sediment cores (Plate 1 Figs. 4-6; Plate 2 Figs. 1, 2). They are spreiten burrows showing a widely varying morphology. However, they can be grouped into a few categories - helicoidal, trumpet- and tonguelike forms-according to the position of the feeding part in relation to the vertical central part (Wetzel and Werner, 1981).

The circular or lobate, sheetlike spreiten burrows are flat, curved, inclined, or sometimes helicoidally wound around a vertical axis. In vertical core sections Zoophycos burrows appear as horizontal, subhorizontal, or slightly inclined tabular structures, ranging from 2 to about $10 \mathrm{~mm}$ in thickness. Internally they show the characteristic chevronlike structures created during backfilling with alternating fine and coarse sediment-sometimes clearly pelleted. Sections parallel to the bedding plane of Zoophycos spreiten reveal the string of beads pattern of pelleted lamellae (Plate 2, Fig. 2). Larger burrows of the helicoidal type occur infrequently in core sections and show up to eight windings of spreiten (Plate 2, Fig. 1). Though different types of Zoophycos are recognizable on the base of size, shape, and pattern of the 
lamellae in the spreiten (Ekdale, 1974), I made no division into ichnospecies for this investigation because of probable transitions between the types (Wetzel and Werner, 1981).

Chondrites is a common and widespread trace fossil of which several dozens of varieties are reported. Principally it consists of a vertical shaft branching in rootlike fashion into numerous primary and secondary branches which never anastomose or cut across each other and are ramified at particular angles $\left(30^{\circ}-40^{\circ}\right)$. Although the animal producing these traces worked down from the sediment interface, its main activity is limited to distinct horizontal strata in which it apparently searched for nutrient-rich layers.

In vertical core sections Chondrites (Plate 3, Figs. 1-6) appears in clusters of small circular or elongated tube sections, some 1 to $5 \mathrm{~mm}$ in diameter, and-depending on the angle between section and burrow-as irregular subhorizontal lines (Plate 3, Fig. 3). If visible, the vertical shaft does not go straight up but is slightly meandering. In addition it always shows a light or dark halo, depending on its color (Plate 3, Figs. 1, 4). Probably many of the smaller secondary traces making up the composite burrows are of Chondrites or Helminthopsis origin as well (Wetzel, 1981).

Teichichnus is a long but narrow, troughlike system of spreiten. Upward migration of the animal in a (probably) cylindrical U-shaped tube produces an internally laminated vertical to subvertical trace. In transverse core sections Teichichnus is recognized as vertical columns with internal, thin, concave-upward laminae (Plate 4, Fig. 1). They range from 5 to $20 \mathrm{~mm}$ across and from 10 to about $200 \mathrm{~mm}$ high. Lateral boundaries of this trace type normally are parallel (Plate 4, Fig. 1); Some are irregular (Plate 4, Figs. 2, 3).

Composite burrows consist in general of one larger or primary burrow and of one or several smaller, secondary burrows within the larger structure. In Leg 74 cores the primary burrows are represented mainly by Planolites types, and the secondary structures are generally formed by Chondrites types (Plate 1, Figs. 2, 3). However, no serial sections were made to distinguish between the predominantly straight traces of Chondrites and the meandering structures of Helminthopsis, both of which are known to follow Planolites structures (Chamberlain, 1975; Wetzel, 1981).

In this study composite burrows are considered as a separate category only if they are especially large or conspicuous; otherwise they are lumped with the primary structure (mainly Planolites) or with the secondary structure (mainly Chondrites), depending on the prevailing trace type.

Halo burrows are present in great numbers. They consist of simple burrows (e.g., Planolites) or composite burrows showing a halo of lighter sediment around the central burrow structure. The color change of the halo is gradational (Plate 4, Fig. 4) and varies in size from a few millimeters to some centimeters in cross section. The halo probably is a diagenetic effect due to the alteration of organic material left by the burrowing organism. Halo burrows are most abundant in slightly consol- idated carbonate oozes, and are often the only recognizable trace type (see photograph of Cores 525B-1 and $528 \mathrm{~A}-1$, this volume).

In this study halo burrows are considered as a distinct group only if the proper genetic burrow type could not be identified. Where identifiable Planolites or Chondrites show halos (Plate 4, Fig. 2), the traces are included in the appropriate ichnogenus.

Rind burrows consist of tiny (1-2 mm wide) cylindrical, straight tubes, usually occurring parallel or slightly inclined to the bedding plane. Small flat-ellipsoidal to lenselike, mainly dark dots are visible and contrast sharply with a slightly lighter halo (Plate 2, Figs. 5-7). Under the microscope they show a thin, dark, more consolidated outer layer called "rind" and a lighter center which is nevertheless darker than the surrounding sediment. This highly specific burrow type occurs only in the more consolidated parts of the deeper Sites 529, 528, and 527.

Vertical burrows of considerable dimension, which are not be related to a specific ichnogenus but which may represent a thallassinoid type, were observed locally (Plate 2, Fig. 4). They are up to $1 \mathrm{~cm}$ wide and can reach $25 \mathrm{~cm}$ in height and extend straight or be slightly sinuous. They usually occur in the more indurated material.

Pyritized burrows are present at one site only. Three morphological types can be distinguished, all consisting of densely packed tubes of pyrite the length of which is limited by the core diameter: (1) slender straight to slightly sinuous, burrows circular in sections, $2 \mathrm{~mm}$ wide (Plate 4, Figs. 5, 6); (2) thick, irregularly bent, cylindrical burrows, about $5 \mathrm{~mm}$ wide (Plate 4, Fig. 7); and (3) firm, slightly curved burrows, flat ellipsoidal in sections, similar to collapsed tubes, 5 to $10 \mathrm{~mm}$ wide (Plate 4, Fig. 8).

Cross sections of the burrows show that the tubes were filled primarily with clusters of framboidal pyrite which now are extensively recrystallized, producing a denser structure. It is unlikely that the pyrite has replaced a primary limonite cement within the burrows (as described by Nilsen and Kerr [1979] from pyritized burrows occurring in mudstones of the Norwegian Sea); instead it was probably precipitated at a very early stage of diagenesis within a highly limited reducing microenvironment.

\section{TRACE FOSSIL DISTRIBUTION}

Distribution of trace fossils and intensity of bioturbation in Leg 74 cores in relation to sub-bottom depth and age are summarized in Figures 2-6. Distribution of distinct trace fossil groups is shown by different capital letters, frequencies of which are proportional to the relative abundance of that trace type in the core. Supplementary observations on primary sedimentary structures, on macrobody fossils, and on diagenetic alterations are included as well.

At Site 526 (1054 $\mathrm{m}$ water depth) bioturbation is recognized only in a sediment sequence of late Miocene to Pliocene age from Hole 526A (Fig. 2). A pure, sandy, nannofossil-foraminifer ooze reveals minor to moder- 


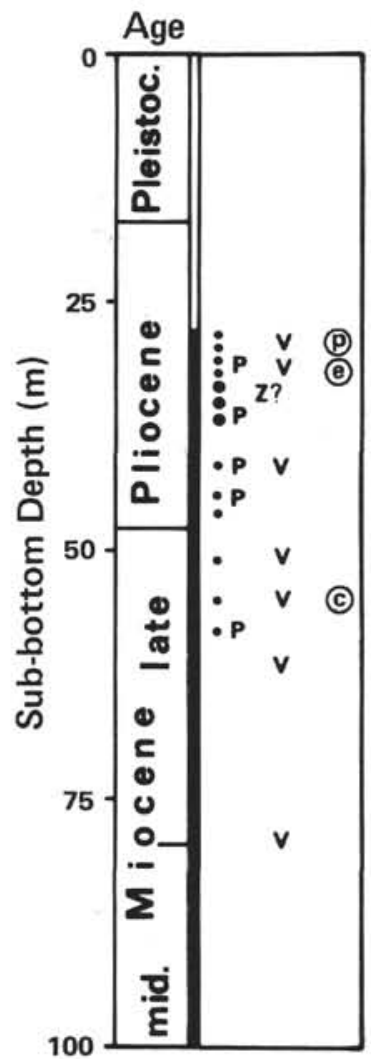

Figure 2. Distribution of bioturbation and trace fossils in Hole 526A (e)= echinoderms; (C)= solitaire coral; $(\mathrm{D})=$ pelecypods; for explanation of remaining symbols, see Fig. 4).

ate bioturbation, which is indicated by some mottling and by the presence of Planolites. The main characteristic of this sediment, however, is the occurrence of numerous pyritized burrows of different types (Plate 4, Figs. 5-8). Similar pyritized burrows from white calcareous oozes are reported from Pleistocene sediments of the Pacific (Chamberlain, 1975). All other sites, in greater water depths (Site 525, $2467 \mathrm{~m}$; Site 529, $3035 \mathrm{~m}$; Site 528, $3800 \mathrm{~m}$; Site 527, $4428 \mathrm{~m}$ ), show distribution patterns different from that of Site 526 but similar to each other (Figs. 3-6).

Minor to moderate bioturbation-indicated mainly by diffused mottling, to a lesser extent by halo burrows, and occasionally only by the presence of Planolites-is present in Pleistocene pelagic oozes of less than $20 \mathrm{~m}$ sub-bottom depth. Below this depth, there exists at all sites a long interval of soft calcareous nannofossil oozes where trace fossils and bioturbation are rare. Consolidation and, simultaneously, slight bioturbation increase downhole to the level of the first occurrence of chalk layers.

As the number of chalk layers increases with sub-bottom depth, so does the intensity of visible bioturbation. Below the transition from chalk and ooze to pure chalk, sediments at all sites reveal strong bioturbation, indicated mainly by high abundances of such trace fossils as Planolites, Zoophycos, and Chondrites as well as by relatively high diversity.

The sub-bottom depth at which these transitions occurs differs considerably from site to site. The same is true for the age of the ooze/ooze and chalk boundary. The chalk and ooze-chalk transition, however, at all sites fits well to a quite narrow interval of middle to late Paleocene age (NP5-NP8).

\section{PRESERVATION}

Preservation of trace fossils in DSDP cores is controlled by a variety of factors. Most obvious are the effects of the drilling process, ranging from nonrecovery to various types of drilling deformation of the cores. The newly developed hydraulic piston corer (HPC), however, reduces the amount of drilling disturbance-which had been particularly severe in the upper $100-200 \mathrm{~m}$ of weakly consolidated sediments-so that undisturbed cores of soft sediments are now available.

Other aspects of preservation can be summarized as variation in the perceptibility of traces caused by textural differences or other inhomogeneities. Because of the fine-grained, homogeneous nature of the pelagic sediments recovered during Leg 74 , there was little chance for trace fossils to be preserved by textural differences. Examples are rare in which bioturbation occurs at an interface between different lithologies (e.g., ash or turbidite layers intercalated in the monotonous pelagic oozechalk sequence [Plate 2, Fig. 3: Plate 4, Fig. 1]).

Trace fossils show up mainly as dark or light markings against light or dark backgrounds, respectively. With depth, however, a clear succession in burrow contrast becomes evident. Within the topmost sections of Pleistocene age, burrow color at first fades with depth and age. With increasing depth, however, there is a general improvement in color contrast accentuating the burrows, an effect first noted by Berger et al. (1979) and probably due to subtle geochemical processes produced by reduction-oxidation during diagenesis affecting still unknown (but probably organic) substances producing the color contrast. If, however, organic matter is one of the governing factors in creating color contrast, those organisms that either produce feces rich in organic matter or coat their burrows with such slime have the best chance to be preserved as trace fossils.

Furthermore, the intensity of visible bioturbation and occurrence of trace fossils is substantially dependent on the degree of consolidation and induration during lithification from ooze to chalk to limestone. Nonindurated sediments that show no visible bioturbation structures may still be bioturbated.

The primary interest in considering trace fossils preservation is to determine which traces of benthic activity have the best chance of becoming fossilized. Because biological activity is highest at the sediment surface and decreases with depth, the surface trails often seen on deepsea photographs (Heezen and Hollister, 1971; Hollister et al., 1975; Ekdale and Berger, 1978) are usually reworked rather than transmitted to the fossil record in a normal, continuous pelagic sedimentation. Berger et al. (1979) describe a rather homogeneous mixed layer in the upper part of vertical box cores containing a dense network of tiny burrows which are not preserved. They interpret this layer to be produced by intense bioturbation of small organisms under environmental conditions in which burrow destruction exceeds burrow construction. 

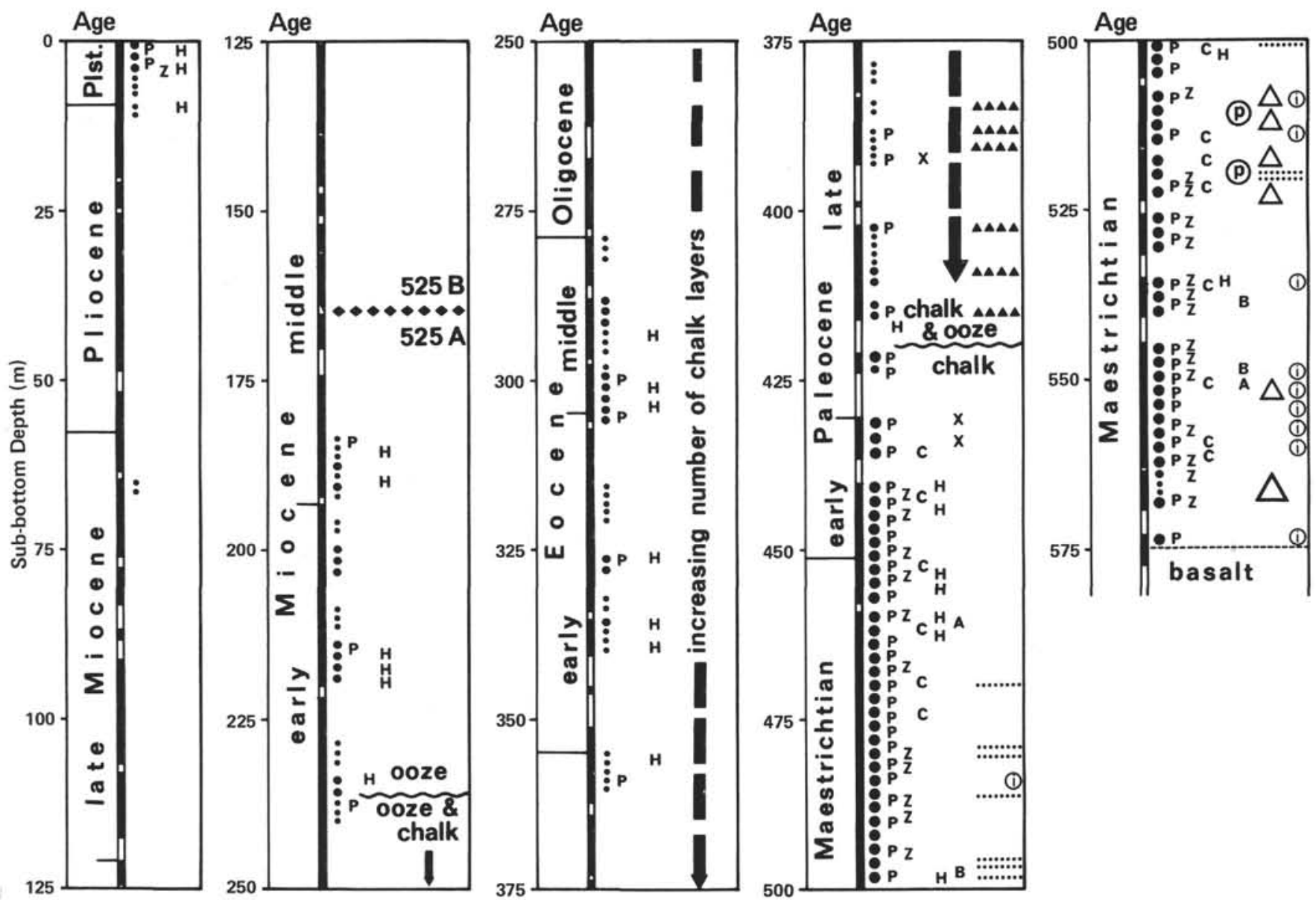

Figure 3. Distribution of trace fossils and intensity of bioturbation in Holes 525A and 525B (for explanation of symbols, see Fig. 4).

That means that no surface trails, but only infaunal traces that are burrows, are preserved. Among this group, the burrows produced last and deepest in the sediment have the best chance of preservation. This interpretation leads to the model of "bioturbation levels" (Wetzel, 1981; Werner and Wetzel, in press). This model suggests that infaunal sedimentary structures are arranged in a systematic succession of burrow assemblages with increasing sediment depth (Fig. 7). This succession observed in Recent sediment cores from the northwest African continental margin is characterized by a biologically homogenized level $\mathbf{A}(=$ homogeneous mixed layer, Berger et al., 1979), a Scolicia assemblage at level B, a Planolites assemblage at level C, a Chondrites assemblage at level D, and a bottommost Zoophy$\cos$ assemblage at level $\mathrm{E}$. This model of bioturbation levels can be tested by direct observation of burrow depth in modern sediments but only indirectly in fossil sediments by analyzing successions of different burrows crosscutting each other.

Comparison of the trace fossil assemblage observed in Leg 74 cores with the model succession shown in Figure 7 illustrates first that the model fits the observed succession (Chondrites crosscuts or follows Planolites, Zoophycos crosscuts both) and, second, that only burrows of the deeper levels C, D, and E are preserved.

\section{PALEOBATHYMETRY}

The bathymetric evolution of Leg 74 Sites on the Walvis Ridge is shown in the depth-time diagram of Figure 8. The main groups of trace fossils observed in the core sequences are included alongside each site and show some noticeable differences:

1) Planolites, the most cosmopolitan trace type, occurs in all water depths from the Maestrichtian to Recent. Differences in abundance are probably due to preservation.

2) Halo burrows tend to occur preferentially in the deeper sites. They are present in large numbers in the Maestrichtian from 1000 to $2000 \mathrm{~m}$ in the upper Paleocene from 2000 to $3500 \mathrm{~m}$, and in the lower Miocene from 3500 to $4500 \mathrm{~m}$ water depth. In water depths below $2000 \mathrm{~m}$, halo burrows are present occasionally from Paleocene to Recent.

3) Chondrites and Zoophycos show a very similar distribution pattern. High abundance occurs in the Maestrichtian at a water depth ranging from a few 100 to $2000 \mathrm{~m}$ and in the upper Paleocene at a depth from 2000 to $3500 \mathrm{~m}$. Only scattered observations were obtained at 3500 to $4500 \mathrm{~m}$ water depth in upper Paleogene and Neogene sections, which may be related to sediment type, compaction, or the drilling method used. 

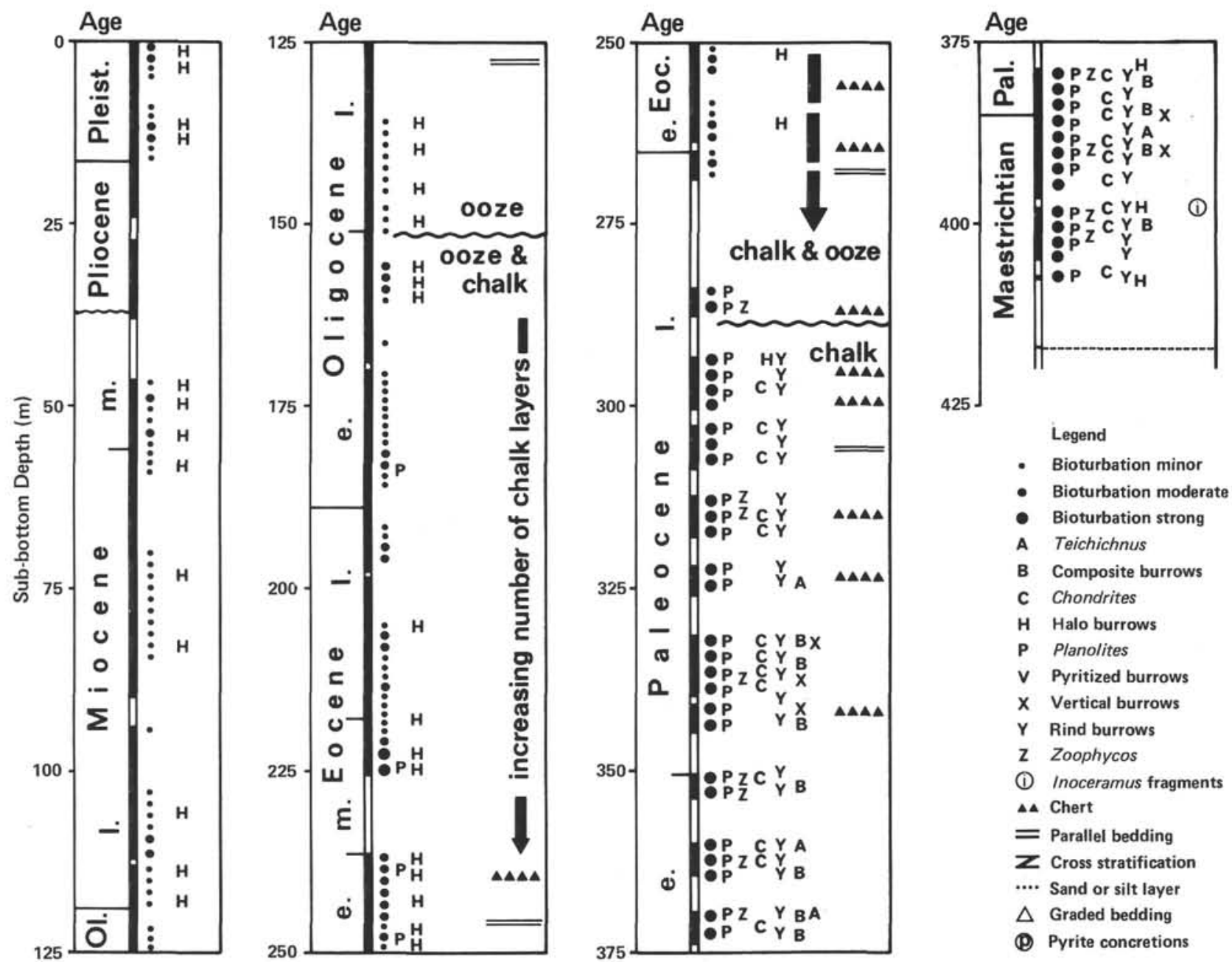

Figure 4. Distribution of trace fossils and intensity of bioturbation in Hole 529.

4) Pyritized burrows are restricted to a water depth of about $1000 \mathrm{~m}$ during the Miocene to Pliocene at Site 526.

\section{DISCUSSION}

Many attempts have been made to deduce paleobathymetry from trace fossils or trace fossil assemblages. There is now a general agreement to classify ichnofaunal communities according to their environmental conditions as these relate to water depth (Chamberlain, 1978; Seilacher, 1978). However, it has to be noted that high diversity of trace fossils, giving a relatively close sequence of bathymetric zones, is confined mainly to shallow water-depths of less than $180 \mathrm{~m}$ (Chamberlain, 1978). Only a few trace fossil types occur in the bathyal or abyssal depths of the oceans. For that reason only wide-scale bathymetric zonation is expected in oceanic basins. Moreover, it is important to note that the studies just mentioned provide only relative depth scales, not exact numbers. Following the bathymetric zonation of Seilacher (1978), which is deduced mainly from the Paleozoic fossil record, the trace fossil community of the Walvis Ridge sediments would fit his $\mathrm{Zo}$ ophycos Zone. This zone is in an intermediate water depth below wave base and the bathyal-that is, in the wide range of roughly 100 to some $3000 \mathrm{~m}$ water depth. This depth assignment is somewhat in contrast (though an overlap of $1000 \mathrm{~m}$ does exist) to observations on Quaternary sediments at the northwest African continental margin (Wetzel, 1981), where Zoophycos today is present only in water depths below $2000 \mathrm{~m}$.

However, it appears from Figure 8 that during Late Cretaceous to Paleogene times, Zoophycos changed its environmental preference to deeper water. This change is certainly not an effect of preservation during the transition from ooze to chalk. Zoophycos disappears in the lower Paleocene at the shallow Site 525, far below the ooze-chalk transition; in the upper Paleocene at the deeper Site 529, just above the ooze-chalk transition; and finally is still present in the Eocene and locally even higher at the deeper Sites 528 and 527. The reason for this is not obvious. Although Zoophycos is reported to be sensitive to environmental factors such as sedimentation rate, nutrient content, and oxic-anoxic properties of the sediment (Wetzel and Werner, 1981), it is highly speculative to favor one factor over the other. During the Paleocene, sedimentation rate in Leg 74 cores decreased because of decreasing input of volcanogenic de- 

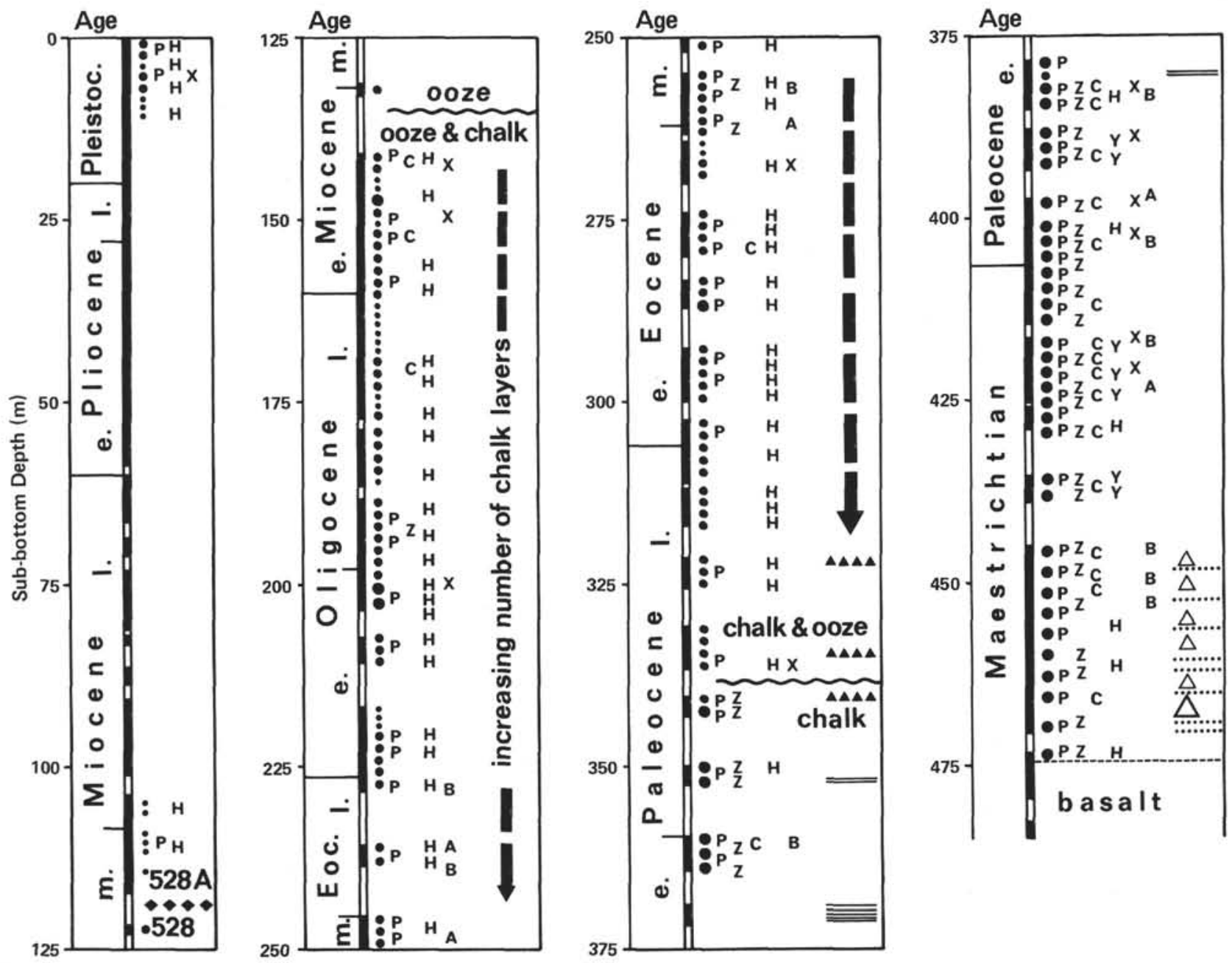

Figure 5. Distribution of trace fossils and intensity of bioturbation in Holes 528A and 528B (for explanation of symbols, see Fig. 4).

tritus. Nutrient content may have also decreased, because the area sank rapidly as the oceanic crust cooled and as the ridge lost its character as a shallow-water archipelago. Consequently hydrographic conditions may also have changed so that Zoophycos could "survive" in greater water depth only.

The increase of visible bioturbation from Pliocene through Pleistocene sections at all sites except Site 526 could be a result of diagenetic color fading with age as reported by Berger et al. (1979). However, it could just as well be an effect of drastic changes in the depositional regime related to the onset of the Pleistocene glacial epoch. It is not clear whether fertility or another parameter such as carbonate compensation depth, lysocline, or oxygen content of bottom water is the responsible factor. Clarke (1968) interpreted differences in abundance of burrows from postglacial abyssal sediments in terms of fertility changes. Wetzel (in press) discussed differences in trace fossil diversity in glacial and interglacial sediments off northwest Africa in terms of $\mathrm{C}_{\text {org }}$ accumulation and preservation possibly due to climatically induced changes in water mass circulation.

\section{CONCLUSIONS}

1. The trace fossil community observed in Leg 74 cores from the Walvis Ridge is represented by a few cosmopolitan ichnogenera like Planolites, Chondrites, Zoophycos, and Teichichnus. Rind burrows, halo burrows, and pyritized burrows are other important burrow types present.

2. The trace fossil assemblages are represented by infaunal traces only. They belong exclusively to the deeper levels C, D, and E of the succession of "bioturbation levels" discussed by Wetzel (1981).

3. Visibility of burrows in pure biogenic sediments seems to be dependent mainly on the degree of lithification from ooze to chalk.

4. An obvious increase in bioturbation in uppermost Pliocene to Pleistocene oozes is observed at all deepwater sites.

5. From the age-depth distribution of the burrows it is evident that Zoophycos must have changed its bathymetric preference from shallow water in the Cretaceous to deeper water in the Paleocene to Eocene. 

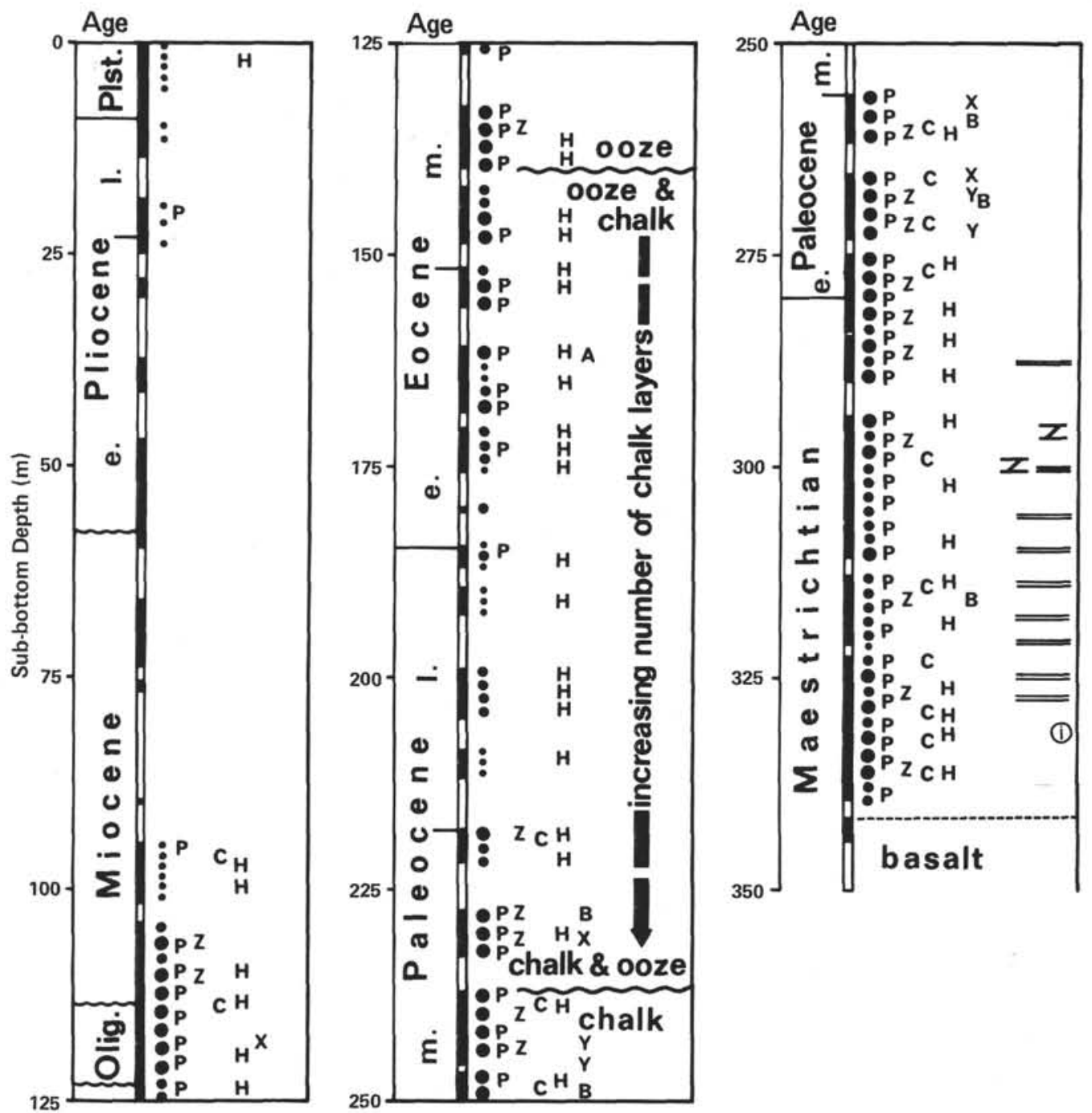

Figure 6. Distribution of trace fossils and intensity of bioturbation in Hole 527. ( $\mathrm{i}=$ Inoceramus fragments;

for explanation of remaining symbols, see Fig. 4).

6. A more detailed bathymetric zonation of the bathyal of the oceans based on trace fossil assemblages may be possible by careful correlation of data and stratigraphic age.

\section{ACKNOWLEDGMENTS}

The author would like to thank W. Coulbourn, C. Samtleben, H. -D. Schulz, and F. Werner for valuable suggestions and critical reading of the manuscript. Technical help by B. Hecht and I. Bornhöft is gratefully acknowledged. Financial support was given by the Deutsche Forschungsgemeinschaft.

\section{REFERENCES}

Berger, W. H., Ekdale, A. A., and Bryant, P. P., 1979. Selective preservation of burrows in deep-sea carbonates. Mar. Geol., 32: 205-230.

Chamberlain, C. K., 1975. Trace fossils in DSDP cores of the Pacific. J. Paleontol., 49:1074-1096.

, 1978. Recognition of trace fossils in cores. In Basan, P. B. (Ed.), Trace Fossil Concepts. SEPM Short Course No. 5: Tulsa (Soc. Econ. Paleontol. Mineral.), 133-183.

Clarke, R. H., 1968. Burrow frequency in abyssal sediments. DeepSea Res., 15:397-400.
Ekdale, A. A., 1974. Geologic history of the abyssal benthos: Evidence from trace fossils in Deep Sea Drilling Project cores [Ph.D. dissert.]. Rice University.

1978. Trace fossils in Leg 42A cores. In Hsü, K. J., Montadert, L., et al., Init. Repts. DSDP, 42, Pt. 1: Washington (U.S. Govt. Printing Office), 821-827.

1980. Trace fossils in Deep Sea Drilling Project Leg 58 cores. In Klein, G. deV., Kobayashi, K., et al., Init. Repts. DSDP, 58: Washington (U.S. Govt. Printing Office), 601-605.

Ekdale, A. A., and Berger, W. H., 1978. Deep-sea ichnofacies: Modern organism trace on and in pelagic carbonates of the western equatorial Pacific. Paleogeogr. Paleoclimatol. Paleoecol., 23: 263-278.

Heezen, B. C., and Hollister, C. D., 1971. The Face of the Deep: New York (Oxford Univ. Press).

Hollister, C. D., Heezen, B. C., and Nafe, K. E., 1975. Animal traces on the deep-sea floor. In Frey, R. W. (Ed.), The Study of Trace Fossils: New York (Springer), pp. 493-510.

Nilsen, T. H., and Kerr, D. R., 1979. Turbidites, redbeds, sedimentary structures and trace fossils observed in DSDP Leg 38 cores and the sedimentary history of the Norwegian-Greenland Sea. In Talwani, M., Udintsev, G., et al., Init. Repts. DSDP, Suppl. to Vols. 38, 39, 40, and 41: Washington (U.S. Govt. Printing Office), 259-288. 
Seilacher, A., 1967. Bathymetry of trace fossils. Mar. Geol., 5: 413-428.

1978. Use of trace fossil assemblages for recognizing depositional environments. In Basan, P. B. (Ed.), Trace Fossil Concepts, SEPM Short Course No. 5: Tulsa (Soc. Econ. Paleontol. Mineral.), 185-201.

van der Lingen, G. J., 1973. Ichnofossils in deep-sea cores from the southwest Pacific. In Burns, R. E., Andrews, J. E., et al., Init. Repts. DSDP, 21: Washington (U.S. Govt. Printing Office), 693-700.

Warme, J. E., Kennedy, W. J., and Schneidermann, N., 1973. Biogenic sedimentary structures (trace fossils) in Leg 15 cores. In Edgar, N. T., Saunders, J. B., et al., Init. Repts, DSDP, 15: Washington (U.S. Govt. Printing Office), 813-831.

Werner, F., and Wetzel, A., in press. Palecological interpretation of biogenic structures in North Atlantic sediments. Bull. Inst. Geol. Bassin Aquitaine.

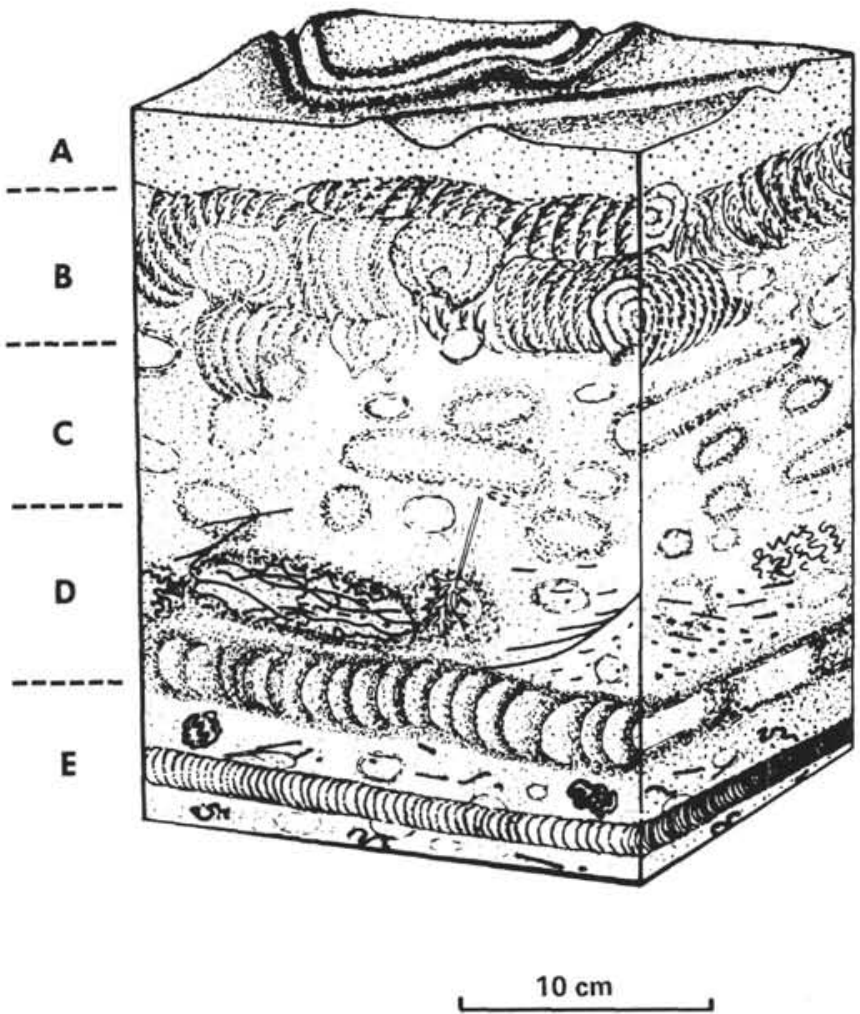

Figure 7. Schematic diagram of "bioturbation levels"' in deep-sea sediments. ( $\mathrm{A}=$ biologically homogenized level, $\mathrm{B}=$ Scolicia level, $\mathrm{C}=$ Planolites level, $\mathrm{D}=$ Chondrites, Helminthopsis, Lophoctenium, Teichichnus level, $\mathrm{E}=$ Zoophycos level [from Wetzel, 1981].)
Wetzel, A., 1981. Ökologische und stratigraphische Bedeutung biogener Gefüge in quartären Sedimenten am NW-afrikanischen Kontinentalrand. "Meteor"' Forsch. Ergebnisse, C, 34:1-47.

in press. Biogenic sedimentary structures in a modern upwelling area: The NW African continental margin. In Suess, E., and Thiede, J. (Eds.), Coastal Upwelling: Its Sediments Record, NATO Conference Series: New York (Plenum Press).

Wetzel, A., and Werner, F., 1981. Morphology and ecological significance of Zoophycos in deep-sea sediments off NW Africa. Paleogeogr. Paleoclimatol. Paleoecol., 32:185-212.

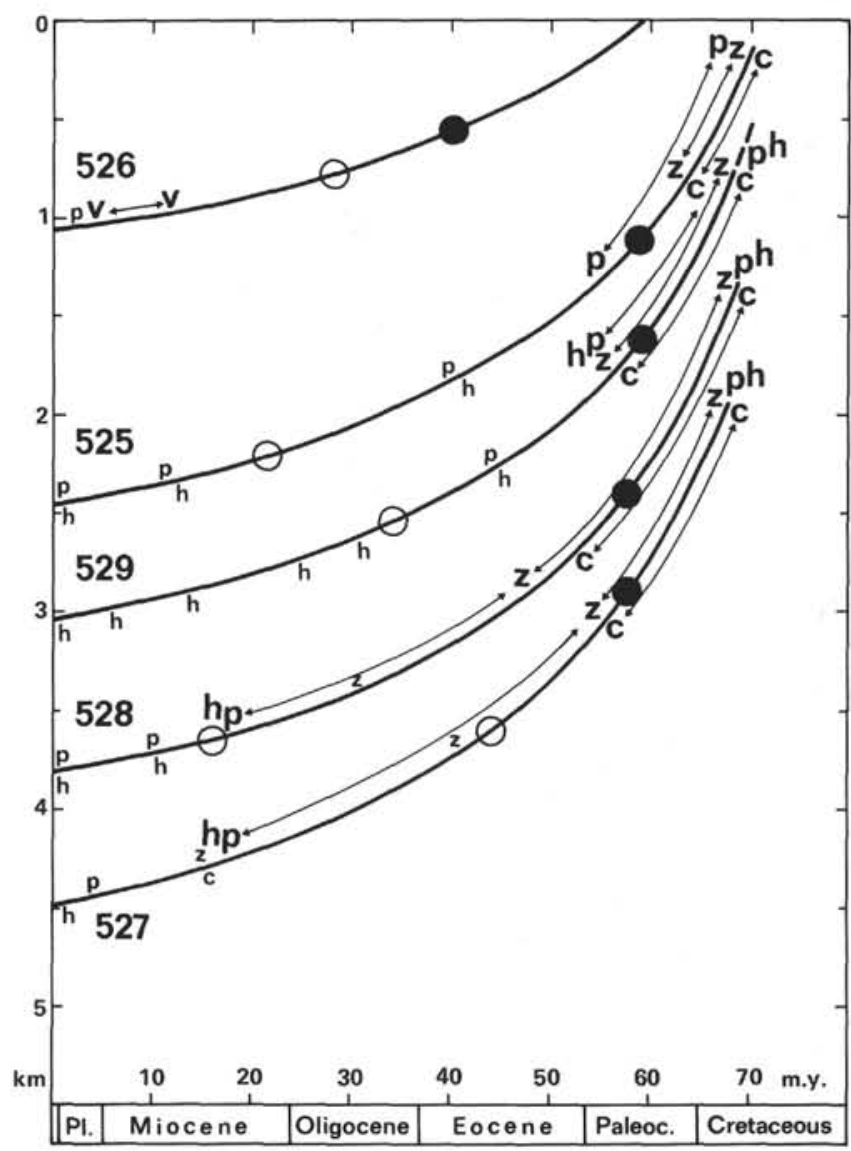

Figure 8. Bathymetric evolution of Sites 525, 526, 527, 528 and 529 (Walvis Ridge, Leg 74) and distribution of trace fossils. ( $c=$ Chondrites, $\mathrm{h}=$ halo burrows, $\mathrm{p}=$ Planolites, $\mathrm{z}=$ Zoophycos, $\mathrm{v}=$ pyritized burrows; small letters indicate local occurrence only, fat letters and arrows in between indicate high abundancy in the complete marked interval. $\mathrm{O}=$ ooze-ooze and chalk transition; - = chalk-and-ooze to chalk transition. 

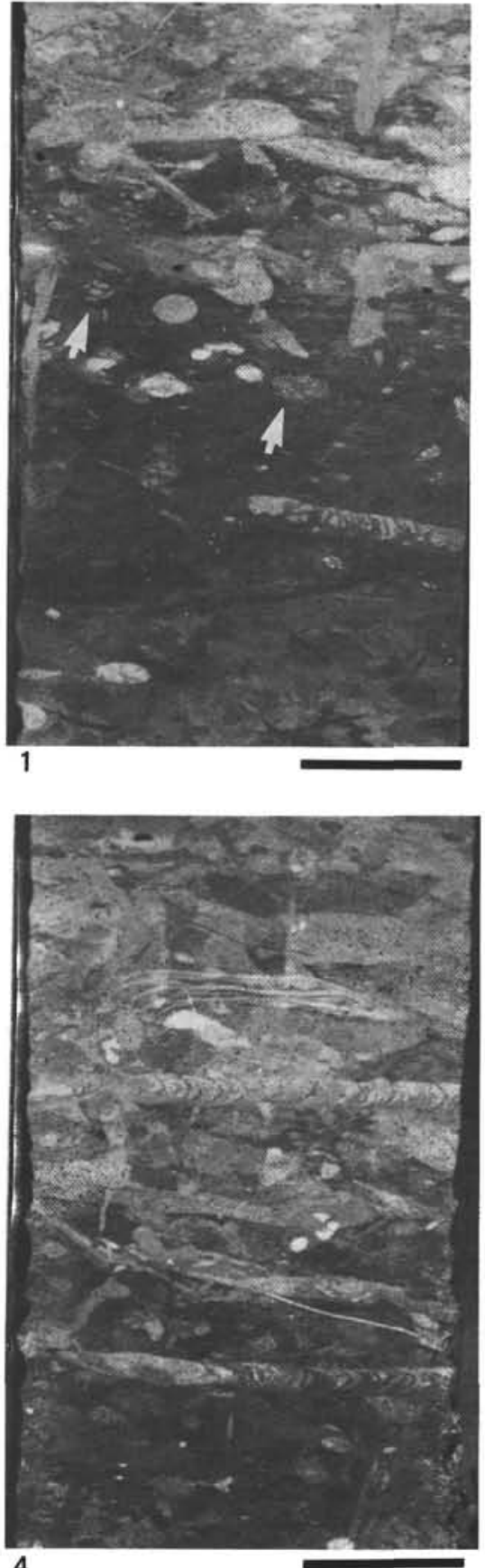

4
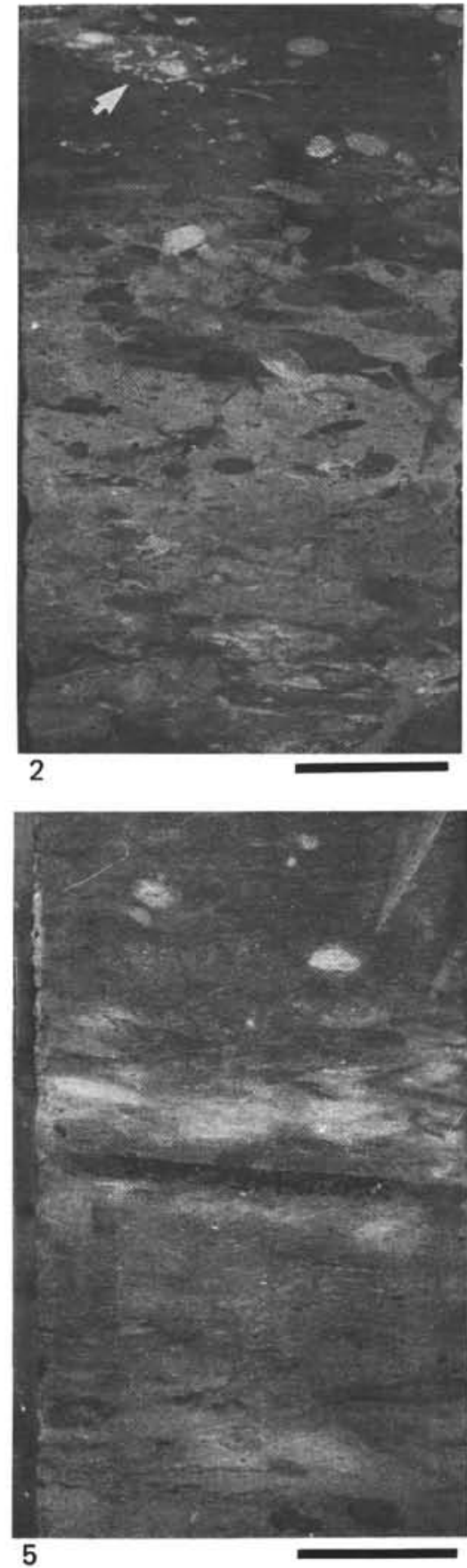

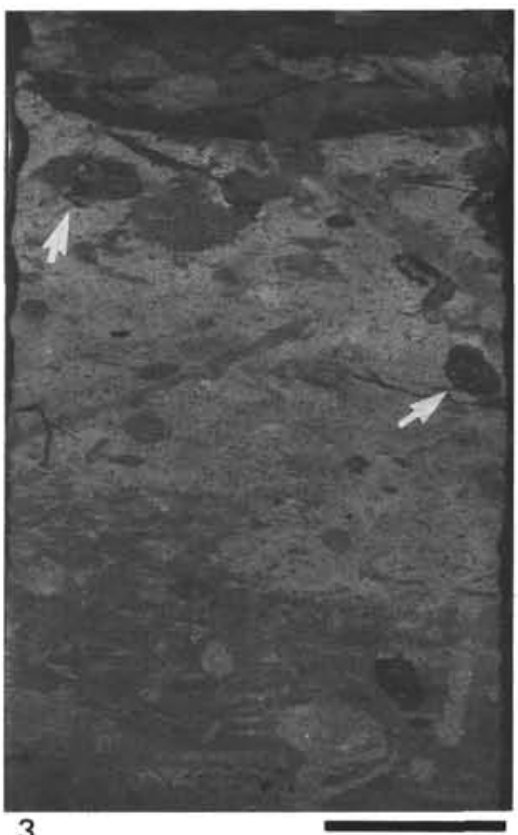

3

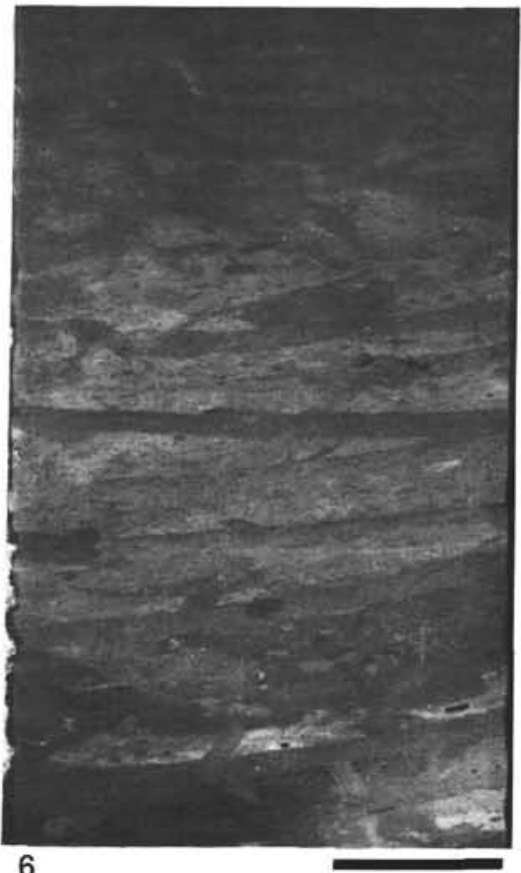

6

Plate 1 (Bar scales = 2 cm). 1-3. Early Paleocene examples of Planolites in vertical and oblique sections partly connected with Chondrites to produce composite burrows (arrows), (1) Sample 528-29-4, 60-70 cm, nannofossil chalk; (2) Sample 528-30-2, 60-70 cm, foraminifer nannofossil chalk; (3) Sample 528-29-4, 81-90 cm, nannofossil chalk. 4-6. Early Paleocene examples of different types of Zoophycos, (4) several parallel sheets of simple Zoophycos in strongly bioturbated nannofossil chalk, Sample 528-29-4, 70-80 cm; (5) pelleted Zoophycos, Sample 529-41-1, 6-14 cm, foraminifer-nannofossil chalk; (6) several sheets of slightly curved Zoophycos, Sample 528-30-4, 52-61 cm, foraminifer-nannofossil chalk. 

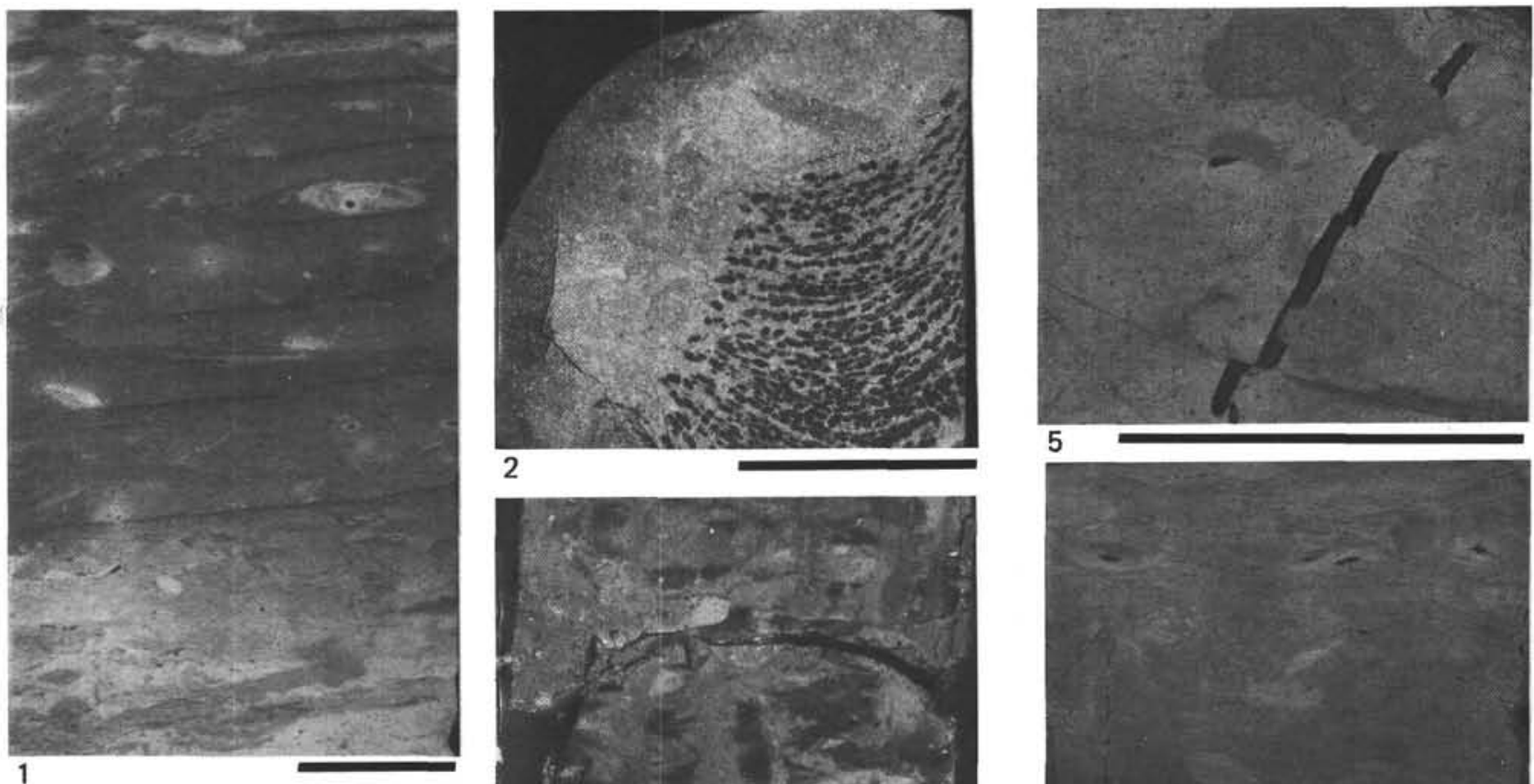

2
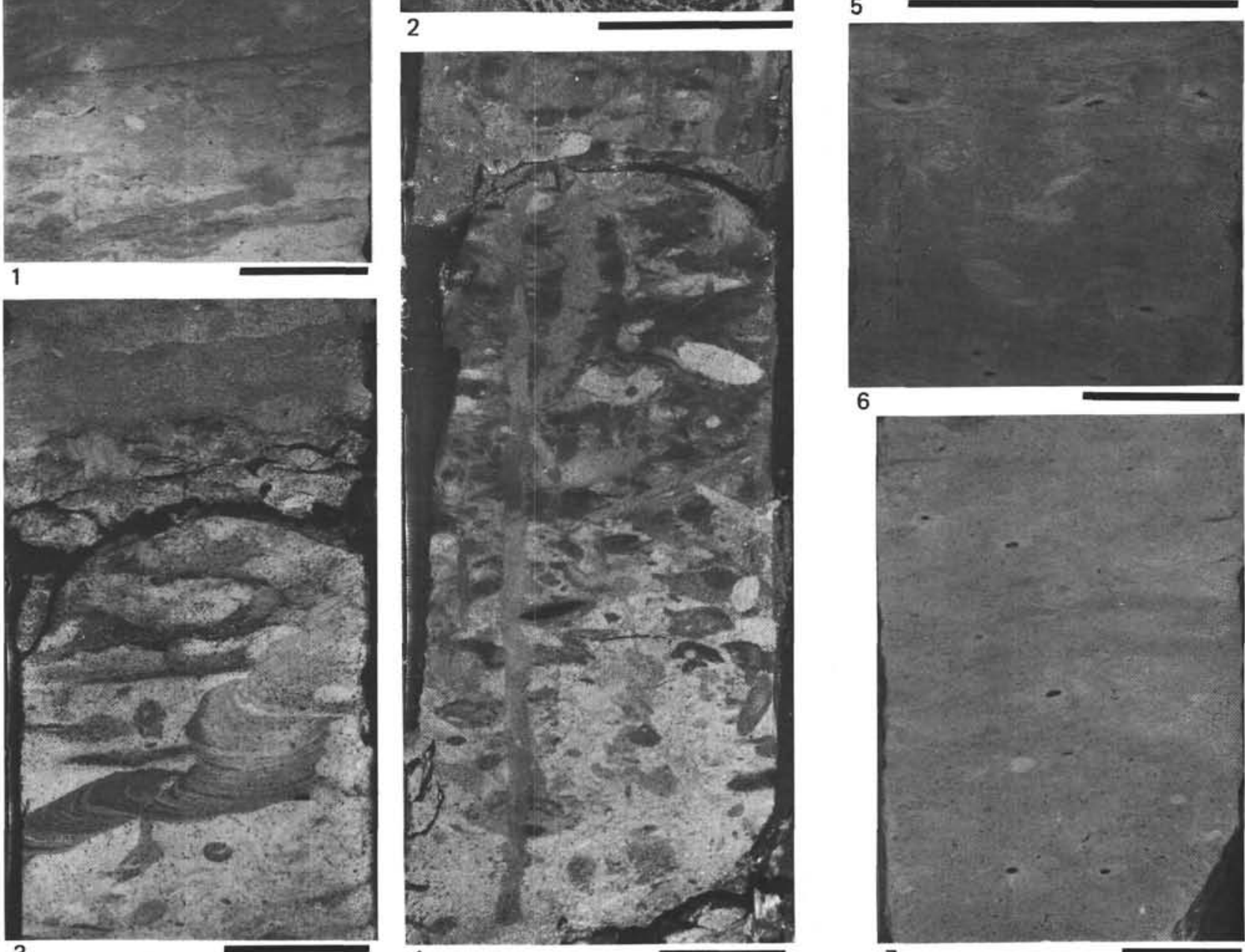

3
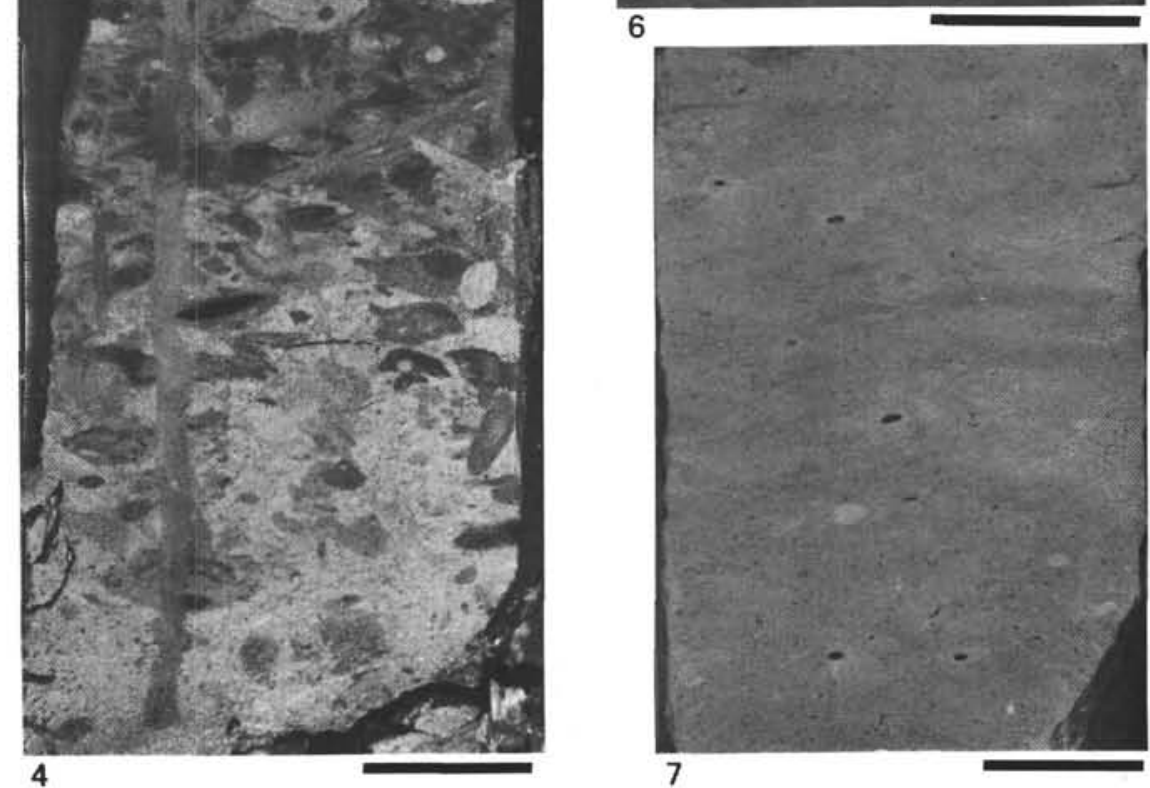

Plate 2 (Bar scales $=2 \mathrm{~cm}$ ). 1. Cross section of equally spaced parallel sheets of Zoophycos spreiten representing a nearly complete burrow of helicoidal type, Sample 528-31-2, 20-29 cm, early Paleocene foraminifer-nannofossil chalk. 2. Horizontal section of pelleted Zoophycos spreiten showing arrangement of fecal pellets in distinct laminae, Sample 529-41-1, 9-10 cm, early Paleocene foraminifer-nannofossil chalk. 3. Oblique section of a spreiten burrow, possibly Teichichnus lying beneath a nearly completely reworked turbidite layer, Sample 525A-41-4, 73-82 $\mathrm{cm}$, Late Cretaceous indurated nannofossil chalk. 4. Large vertical burrow, Sample 527-30-2, 36-50 cm, early Paleocene foraminifer-nannofossil chalk. 5-7. Rind burrows, (5) horizontal section showing darker rind and irregular light halo around, Sample 529-33-2, 87-88 cm, late Paleocene foraminifer-nannofossil chalk; (6) Sample 529-37-1, 114-118 cm, late Paleocene nannofossil chalk; (7) Sample 529-36-3, 140-152 cm, late Paleocene nannofossil chalk. 

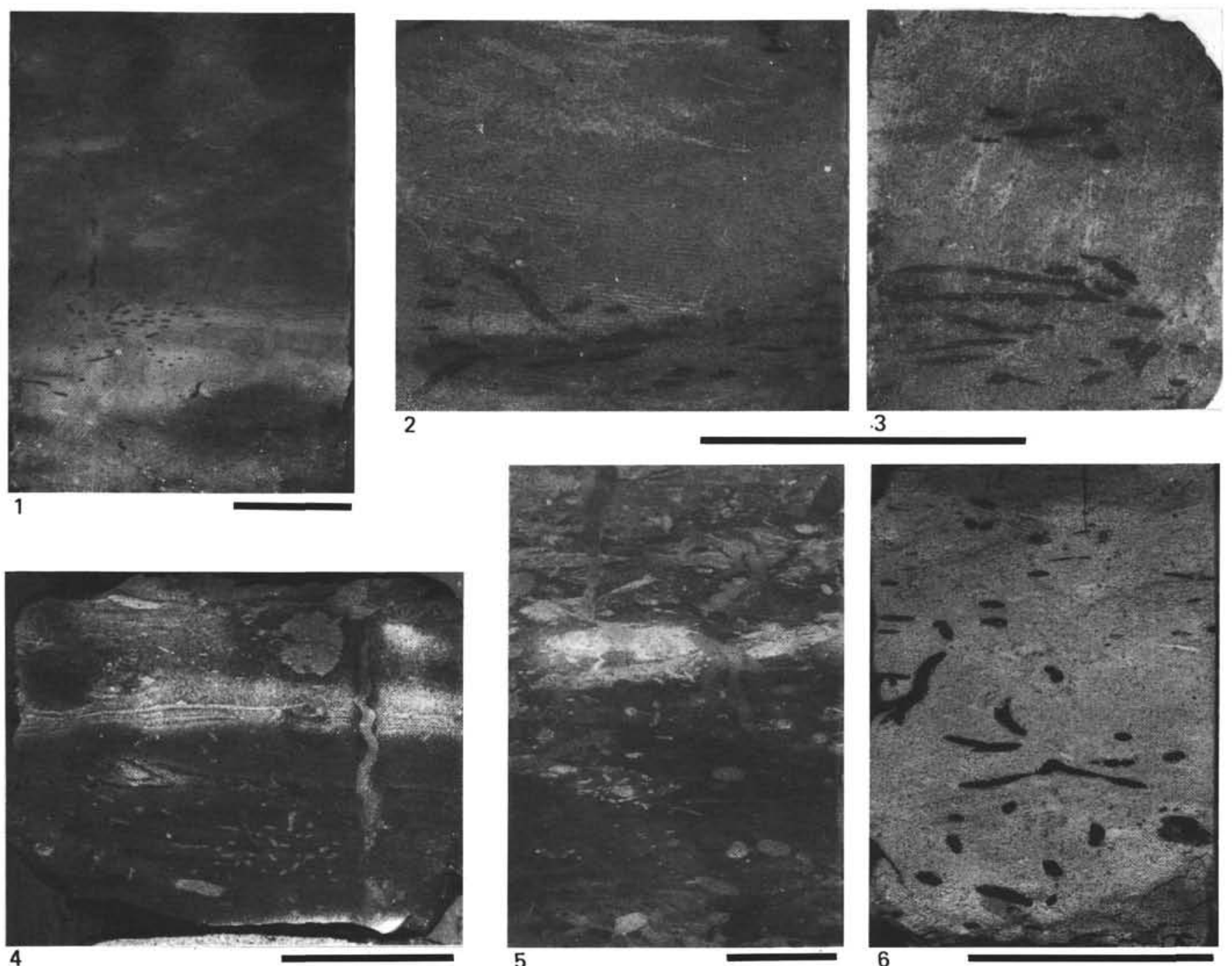

Plate 3. Examples of Chondrites (bar scales $=2 \mathrm{~cm}$ ). 1. Cluster of Chondrites and slightly meandering shaft with halo, Sample 528-33-1, 134-143 cm, Late Cretaceous indurated nannofossil chalk. 2-3. Two surfaces at $90^{\circ}$ angle showing horizon bound clusters of Chondrites, Sample 528-31-7, 65-67 cm, early Paleocene foraminifer-nannofossil chalk. 4. Cluster of Chondrites and meandering shaft with halo, Sample 528-43-1, 67-71 cm, Late Cretaceous muddy limestone. 5. Clusters of Chondrites partly bound to Planolites as composite burrows; several meandering vertical burrows possibly represent shafts of Chondrites, Sample 528-30-2, 55-63 cm; early Paleocene foraminifer-nannofossil chalk. 6. Nearly complete specimen showing radiating probes very near the shaft, Sample 529-41-3, 135-139 cm, early Paleocene foraminifer-nannofossil chalk. 

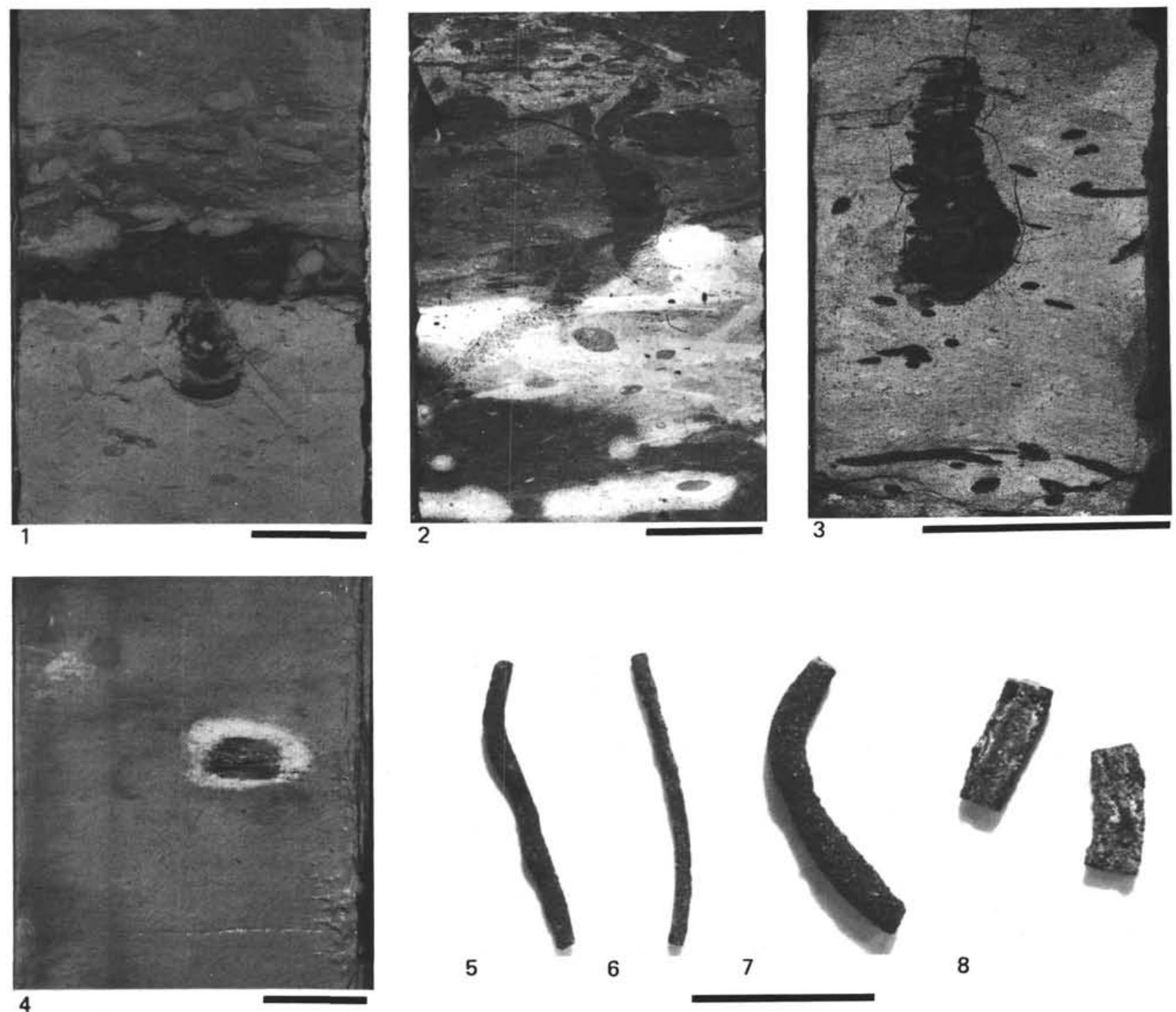

Plate 4 (Bar scales $=2 \mathrm{~cm}$ ). 1-3. Examples of Teichichnus, (1) specimen clearly showing that internal laminae resulted from reworking of overlying volcanic ash layer, Sample 529-35-1, 21-29 cm, late Paleocene foraminifer-nannofossil chalk; (2) specimen of Teichichnus among Planolites and one very inclined Zoophycos?, large discolored areas and halos, Sample 528-31-5, 69-78 cm, early Paleocene foraminifer nannofossil chalk; (3) cross section of complete specimen showing thick internal laminae, Sample 529-41-3, 135-139 cm (same sample as in Plate 3, Fig. 6), early Paleocene foraminifer-nannofossil chalk. 4. Halo burrow from soft early Miocene nannofossil ooze, Sample 529-8-5, 130-137 cm. 5-8. Pyritized burrows of different types from pure nannofossil foraminifer ooze, (5) Sample 526A-4-2, $60 \mathrm{~cm}$, early Pliocene; (6) Sample 526A-8-1, $70 \mathrm{~cm}$, late Miocene; (7) Sample 526A-6-1, $20 \mathrm{~cm}$, early Pliocene; (8) Sample 526A-12-1, 55-57 cm, late Miocene. 